\begin{tabular}{|c|c|c|c|c|c|c|}
\hline \multirow{4}{*}{ Impact Factor: } & ISRA (India) & $=3.117$ & SIS (USA) & $=0.912$ & ICV (Poland) & $=6.630$ \\
\hline & ISI (Dubai, UAE & $=0.829$ & РИНЦ (Russia) & $=0.156$ & PIF (India) & $=1.940$ \\
\hline & GIF (Australia) & $=0.564$ & ESJI $(\mathrm{KZ})$ & $=8.716$ & IBI (India) & $=4.260$ \\
\hline & JIF & $=1.500$ & SJIF (Morocco) & $=5.667$ & OAJI (USA) & $=0.350$ \\
\hline
\end{tabular}

\section{SOI: $1.1 /$ TAS DOI: $10.15863 /$ TAS International Scientific Journal Theoretical \& Applied Science}

p-ISSN: 2308-4944 (print) e-ISSN: 2409-0085 (online)

Year: 2019 Issue: $06 \quad$ Volume: 74

Published: $22.06 .2019 \quad \underline{\text { http://T-Science.org }}$

SECTION 21. Pedagogy. Psychology. Innovations in the field of education.
QR - Issue

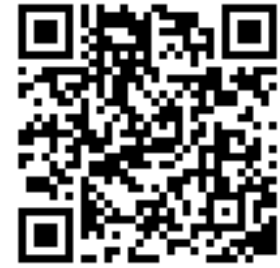

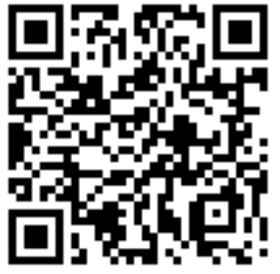

Palina Botirova

Namangan Engineering Construction Institute Teacher of Foreign Languages Department

Robiya Sobirova

Namangan Engineering Construction Institute Teacher of Foreign Languages Department Uzbekistan, Namangan

\title{
FEATURES OF THE TRANSLATION OF POETRY INTO ENGLISH
}

Abstract: This article discusses the features of translating poetry into English. The article deals with the difficulties in translating poetry and ways to solve them. The similarities and differences between Russian and English are analyzed.

Key words: poetry, translation, analysis, Russian, English, literary literature.

Language: English

Citation: Botirova, P., \& Sobirova, R. (2019). Features of the translation of poetry into English. ISJ Theoretical \& Applied Science, 06 (74), 383-387.

Soi: http://s-o-i.org/1.1/TAS-06-74-48

Doi: crossef https://dx.doi.org/10.15863/TAS.2019.06.74.48

\section{Introduction}

This work could be entitled "On not knowing Russian". In the article "On not knowing Greek," she writes about the significance of Greek poetry for a 20th century European. We turn to the Greek culture, tired of the formlessness of life, the vagueness of Christianity, the comfort that it offers, from years lived ... Speaking about the "Russian point of view", Virginia Woolf emphasizes the destructiveness of the translation: "Only the rude, vulgarized, degraded version of the meaning remains alive. After that, Russian classics look like people who have lost their clothes as a result of an earthquake or train wreck. "For us, the idea that in the sky of Russian poetry Tsvetaeva occupies one of the central places is indisputable, she is native and close to every Russian person; for us, undoubtedly, it belongs to the pleiad of those great writers, "whose work has become a living asset of not only national, but also world literature." At the same time, foreigners, speaking of Russian literature, primarily call the names of Dostoevsky, Tolstoy, Gogol, Chekhov. Such an underestimation of Tsvetaev's poetry abroad is due primarily to the fact that translating it into foreign languages is extremely difficult.

\section{Materials and Methods}

How, by what means of a language, to convey to foreign readers all the unique charm, simplicity, sincerity, sincerity of Tsvetaeva's poetic word, all the richness of the sound structure of her poetic speech, without losing the main thing - its bottomless depth of meaning, its spiritual attraction? How to make it so that when reading Tsvetaeva in translations, a citizen of another country gets real pleasure, empathized with Tsvetaev's word, feeling, thoughts, how do we, the Russians, empathize by reading the poetess in her native language? The theory of translation, including artistic, is a science in its infancy. Until now, many of the problems associated with it have not been solved and cause heated debates. Originally emerging as a branch of literary criticism by the mid-twentieth century, translation theory was reoriented to linguistics. However, in the last third of the twentieth century. Many translation scholars have resolutely started talking about the fact that, following this path, the science of translation has reached a dead end.

The idea of the need to overcome one-sidedness in views on translation began to sound more insistent. Austrian researcher M.Snell-Hornby and scientists close to her: C.Rice, G.I. Vermeer proclaimed a "new orientation" in their writings. They propose to consider the theory of translation as an interdisciplinary science - independent and multiperspective in nature. J. Holms and a group of scientists based on the Catholic University in Leuven (J. Lambert, A. Levefre and others) also advocate the interdisciplinary character of literary translation, but 


\begin{tabular}{|c|c|c|c|c|c|c|}
\hline \multirow{4}{*}{ Impact Factor: } & ISRA (India) & $=3.117$ & SIS (USA) & $=0.912$ & ICV (Poland) & $=6.630$ \\
\hline & ISI (Dubai, UAI & $=0.829$ & РИНЦ (Russia & $=0.156$ & PIF (India) & $=1.940$ \\
\hline & GIF (Australia) & $=0.564$ & ESJI (KZ) & $=8.716$ & IBI (India) & $=4.260$ \\
\hline & JIF & $=1.500$ & SJIF (Morocce & $=5.667$ & OAJI (USA) & $=0.350$ \\
\hline
\end{tabular}

they believe that the theory of literary translation should be considered as part of a comprehensive, systematic science of the world literary process (in other words, comparative literature).A translator of a literary text (as, indeed, a translator in general) cannot be considered as a mechanical "switch" in the process of "recoding" - this is exactly the role that is assigned to it from the point of view of semiotics. "

A promising direction in the development of the science of translation, which could help overcome its one-sidedness, is an appeal to the theory of "concept" operating at the interface of linguistics, literature, cultural studies, ethnopsychology and many other sciences.By "concept" is meant a certain "universal", "general idea", fixed in mentality, psyche, language and reproducing a picture of the world and stereotypes of behavior of representatives of one or another ethnic group. A word or action becomes a "concept" only in the process of communication, since communication drives the "bundle" of ideas, associations, experiences that accompanies this "key" word or action."Keywords" is a verbal form of concepts that make up the concept sphere of national consciousness. They draw attention to the frequency of use, they are always the center of the family of phraseological expressions, they are included in proverbs, sayings, titles of popular books, films.

According to Anna Vezhbitskaya, "certain ways of conceptualizing the world are encoded in the words of the language."Every ethnos has at its disposal a huge number of concepts that have developed over the period of its existence, and, consequently, the "key words" for their expression. Among the key ones for English culture are such concepts as "stiff upper lip", "fair play", "gentleman", "home", "freedom", "common sense", "sence of humor". While for Russian culture it is "will", "soul", "fate", "longing", "infinity", "daring", "collegiality", etc. The task of the translator of an artistic text is thus to penetrate into the essence of the "key words" of the original culture and be able to convey their meaning to their readers, retaining, on the one hand, the national flavor of the original, and on the other hand, making the translation perception accessible. for carriers of a completely different national conceptual sphere.In addition, each individual author and each individual work will have their own picture of the world, which is based on certain "keywords". Ignoring this level of meaning also leads to the destruction of the unity of the poetic world of the author and distorts his perception by a foreign reader.A. Blok in his notebooks noted that "every poem is a veil stretched on the edges of several words. These words shine like stars.

Because of them there is a poem."It is clear that when translating an artistic text (poetry in particular) from one language to another, it is impossible not to take these "reference" - "key" words into account. For this, the translator requires literary competence, since the "fullness" of the special meaning of one or another word in the work can be judged to the full extent only by becoming acquainted with the author's poetic world in all its diversity and intricacy of the themes and motives of its components.During the translation, the "supporting" - "key words", on the tip of which, paraphrasing Blok, "stretched out in the text, covered the national concept sphere" are of equal importance. These "keywords", appealing to an unconscious reader belonging to the same culture as the author, create additional dimensions in the perception of the work. At the same time, a translator belonging to a different cultural tradition always risks passing by these important words and, thus, "emasculate" the national spirit of the original. At this level, literary translation is unthinkable without conjugation with ethno-linguistics, cultural studies, and the psychology of culture - sciences that have been booming in recent times. True for the sake of justice, it is worth noting that both levels in practice are usually difficult to separate, since every poet (writer) is deeply national, regardless of whether he expresses this explicitly or not in his work.As an illustration, you can cite the poem by M.I. Tsvetaeva "Motherland" in comparison with his translation into English, made by Joe Shepkott on the 100th anniversary of the birth of Marina Tsvetaeva in 1992. It was published along with translations of other poetess in the magazine "Poetry Review" in the fall of 1993 under the general heading "Thirteen ways to see Marina Tsvetaeva". In addition to Joe Shepkott, who, according to many critics, is one of the brightest poetess of today's UK, equally famous and talented Carol Ann Duffy, Wendy Cope, Ann Stevenson, Fleur Adcock and others also participated in the project.

Tsvetaeva's poem is built on the core opposition "Dal" - "near", which is clearly formulated in the first line of stanza 4: "Dal, which has alienated me to near." The choice of such an opposition as the main core is quite natural, if we recall the circumstances of Marina Ivanovna Tsvetaeva's fate: the poem was written in 1932 in exile. The word "distance" into English cannot be translated without loss of meaning, since it is associated with the "infinity" of Russian spaces. The dictionary of S.I.Ozhegov suggests two meanings: "far place" and "far space visible by the eye". In the poem Tsvetaeva, three meanings are immediately updated by the context:"foreign land" (which has become for the lyrical heroine of Russia). Calling her a "distance", Tsvetaeva not only expresses the idea of remoteness territorial, but also, perhaps even more, the idea of the impossibility of returning. It is not by chance that the expression "distant land" becomes instantly synonymous with the word "Dal", causing immediate association with Russian folk tales, where it means the place where it is almost impossible to reach and which is as far from the speaker as possible, that is, embodies the idea of inaccessibility;- The immense spaces of Russia, which open "and from the Kaluga hill": "But from the Kaluga hill it opens to me 


\begin{tabular}{|c|c|c|c|c|c|c|}
\hline \multirow{4}{*}{ Impact Factor: } & ISRA (India) & $=3.117$ & SIS (USA) & $=0.912$ & ICV (Poland) & $=6.630$ \\
\hline & ISI (Dubai, UAI & $=0.829$ & РИНЦ (Russia & $=0.156$ & PIF (India) & $=1.940$ \\
\hline & GIF (Australia) & $=0.564$ & ESJI (KZ) & $=8.716$ & IBI (India) & $=4.260$ \\
\hline & JIF & $=1.500$ & SJIF (Morocco & $=5.667$ & OAJI (USA) & $=0.350$ \\
\hline
\end{tabular}

- the distance ...";- the immense spaces of the Universe - "to the high stars": "rock, that everywhere, across the distance - I carry it all with me".

The line "distance, which has alienated me from near" in this way becomes key for the poem. Moreover, its interpretation, as is often the case with Tsvetaeva, is ambiguous, "stereoscopic", since the words included in it potentially contain a whole range of meanings. "Dal" here is Russia, as she sees the lyrical heroine from a foreign land. "Near" is Russia before the emigration (because the distance of the heroine turns "near" into "distance"). But this, perhaps, emigration itself, which is not accepted by the lyrical heroine, does not become "near" because there is "distance, innate, like pain" - the Motherland, which does not allow to accept another fate. At the same time, the homeland for her, despite the geographical distance and inaccessibility - near, home, because the love for her - part of the creature of the heroine, "innate, like pain." This love-pain is her rock.Russia is also defined as "the feud of my land," which involuntarily causes associations with feuds that have torn apart Russia in the first half of the twentieth century. But, above all, here we have in mind the discord and discord in the speaker's soul, before which is the question: to return home or not. Moreover, anticipating the real life events of Tsvetaeva, the lyrical heroine is inclined to think about returning, even under the fear of death: "I sign on the chopping block with my lips."In addition, the homeland is presented here as a source of creative inspiration: "Not for nothing, doves of water, I swept my foreheads with a distance.

"The final contextual synonym of the motherland is "pride", which gives all the feelings of the lyrical heroine a shade of sinfulness, the consciousness of which overwhelms her soul with sweet pain. "Motherland" - "pride" - "innate, like pain." The circle closes.Even a brief acquaintance with the poem by Joe Shepkott convinces us that the poetess did not set herself the task of giving the correct translation of Tsvetaeva's poem. It literally translates the name of the color text "Motherland" and, as far as possible by means of the English language, transmits the first line: "Language is impossible ..." (language is useless / impossible). However, as a result, the fluidity of meaning noted in the analysis of the original disappears. After all, the "language" in the phrase "Oh, stubborn language!" can be understood both in the linguistic (what they say) and in the anatomical sense (what they say).The English poem, having adopted only one meaning of the Russian word, switches to a completely different plane: Shepcott takes not life itself, but its reflection in the language, in the work. Therefore, after the word "language" the words appear: "dictionary" (Ovar-repeats twice), "word" (the word is repeated three times) and related words: "syllables" (syllables), "says / say" (says / speak repeats three times), "talks" (talking), in fact, become the "keywords" of Shepcott's poem. And in the line "England. It hurts my lips to shape the word" (England. It hurts my lips to pronounce this word / literally: give shape to this word) the word "word" acts as a contextual synonym for "England".It is curious that the dictionary ("dictionary") appears in the translated poem instead of "the muzhik" in Tsvetaeva: "muzhik, understand, sang before me: Russia, my homeland!". As a result, the fact that in the Russian text came from the people, from within, was innate, original, in the English text it became speculative, intellectual, artificial. Therefore, when it comes to such fundamental things as "England", "Motherland", "Home" ("England", "Homeland", "House"), the language is powerless, and the dictionary laughs at the lyrical heroine.The "distance" of the original turns into a translation poem in "distance" - degree of remotness, interval of space "." Here the line of the poem itself sounds like a dictionary definition. "Distance" when translated back into Russian the language will literally mean "distance", "distance", "remoteness", "gap". True, the English-Russian dictionary edited by Professor V.K. Muller offers, among other meanings, "distance", however, it seems that the word has the opposite meaning to what is embedded in the words "distance". "Distance" necessarily implies "measurement" in meters, kilometers, feet, miles, "orientation" in space and implies certainty, accuracy and orderliness, while "distance" cannot be measured in principle and embodies the Russian concept "infinity".

The row which the English poetess builds attracts attention: "'England', 'Motherland', 'Home'." instead of tsvetaevskogo "Russia, my homeland!". While the Russian "homeland" refers us to the word "clan" and, accordingly, to the concept of "conciliarity", the English "Motherland" and "Home" set different connotations. One of the elements constituting the word "Motherland" - "land" evokes associations with "distance", implies some kind of measurable space, as well as "Home" - the most important component of the English national conceptsphere. "Home" is not just a "home", but, above all, a "home", which necessarily implies for the British to be connected with comfort, well-groomedness, security and privacy. Thus, in Shepkott the word "Home" takes on the opposite meaning to that which Tsvetaeva puts into it when he writes "Come back Home!", Meaning Russia with its vast spaces as "home".In addition, the "house" in the context of the creativity of Marina Tsvetaeva herself acquires additional connotations. According to the observation of ON Osipova in the later poems of the poetess, he loses his traditional function of the center of sacral space and is increasingly associated with emptiness (zero space), death, the grave. Therefore, the call to return "Home" creates a complex set of feelings and experiences: this is a call to return to the life-giving source, and a call to find peace, and with it the last 


\begin{tabular}{|c|c|c|c|c|c|c|}
\hline \multirow{4}{*}{ Impact Factor: } & ISRA (India) & $=3.117$ & SIS (USA) & $=0.912$ & ICV (Poland) & $=6.630$ \\
\hline & ISI (Dubai, UAI & $=0.829$ & РИНЦ (Russia & $=0.156$ & PIF (India) & $=1.940$ \\
\hline & GIF (Australia) & $=0.564$ & ESJI (KZ) & $=8.716$ & IBI (India) & $=4.260$ \\
\hline & JIF & $=1.500$ & SJIF (Morocce & $=5.667$ & OAJI (USA) & $=0.350$ \\
\hline
\end{tabular}

repose, the thirst of which attracts and scares the lyrical heroine at the same time.It is significant that in the English poem the word "rock" is missing. This is a concept that distinguishes the Russian consciousness and is uncharacteristic for the English mentality. Love-pain to the homeland is replaced by pain for the future of England and for the future of the lyric heroine. In Tsvetaeva's "innate", almost an animal sense of homeland, overwhelmingly draws the lyrical heroine back: "Dahl, who said:" Come back Home! "From all - to the high stars - me taking places!". Shepkott's place "gave" to the dictionary, which, laughing, offers the heroine to return home, do not lean out of his protected world, and he takes her farther and farther into star spaces: "Dictionary says laughing, 'Come back HOME', but takes me further and further away into the cold stars "(The dictionary says, laughing:" Come back home, but takes me farther and farther to cold stars ").

\section{Conclusion}

The idea of moving backwards is replaced, therefore, by the idea of moving forward.Although the poem of the English poetess is called "Motherland", the theme of creativity becomes its main theme. Poetic craft, in the interpretation of Joe Shepkott devoid of any kind was a romantic shade. Beyond the limits of ordinary existence: "into the horizon", "into the cold stars" (beyond the horizon, to the cold stars) of the poet is not a genius, not a creative gift, but a dictionary. It is easy to read the postmodern interpretation of the world as a text.The poet does not belong to himself - he is only a transmitter, a mediator who "translates" the space of the world into the words of the human language: "I am nothing, I'm nothing, for aching brows" it only shed syllables for burning pain foreheads). The lyrical heroine lives not in the real world, but in the world of words. Attempting to express one's sense of homeland encourages it, first of all, to turn to vocabulary definitions. However, the language - the conditional code for the inexpressible turns out to be useless, which forces the poetess to begin the poem by stating that it is impossible to put their feelings into words: "In a country, this language is useless). The feeling of belonging to a certain "space" always remains with the lyrical heroine, for whatever boundaries, to whatever transcendental heights she would not rush. Native land, attempts to convey its love for it, the pain for its future - that which impels the poet to work and at the same time makes him feel his helplessness. "The country makes me say too much things I can't say" (This country makes me say too much of what I cannot say). The final phrase: "Home of my rotting pride, my motherland" (literally: the house, (understood as a source and refuge) of my pride, my native land) is read in two ways. We are talking about ambitious attempts of the lyrical heroine to express the inexpressible. But at the same time, the words "rotting pride" inevitably give rise to associations with the fate of today's Britain, which lost its position as an imperial power, as it was at the end of the 19th - early 20th century, and with the fate of the British, in whose minds the current situation of the country came into conflict with the "first-rank" complex that has been formed for decades.

The words "England" and "Home" in the text of Shepkott prevail in terms of frequency of use over the word "Motherland" (3/3/2, if not to take into account the title), while in Tsvetaeva the ratio is different: "homeland" / "Russia "/" home "(4/1/1, also excluding the title). Apparently, for the English mentality in the word "Motherland" there are too many pathos, therefore preference is given to more "chamber" and "home" "England" and "Home".It is noteworthy that for English poetry the name "Motherland" looks very unconventional and even exotic. So, in the authoritative Norton anthology of English literature, consisting of two volumes, each of which contains more than a thousand pages, the poem under this or similar name is not found even once. While in Russian literature with the name "Motherland" is connected a powerful tradition that takes its origins from the poetry of the "Golden Age". The distrust of the English national consciousness to the excessive manifestation of emotions is connected with the almost complete absence of exclamation marks in the poem Shepkott, with which almost every sentence of Tsvetaeva ends (7 out of eight). The only place where the exclamation mark remains is the phrase "Come back HOME!", However, the meaning of its use has been fundamentally changed. He expresses ironic mockery, since direct speech is accompanied by a remark: "says laughing" (speaking, laughing). The dash characteristic of Tsvetaeva's creativity as a whole and the intonation of high emotional tension and intermittent breathing, which is characteristic of her intonation, have also been removed.

They are replaced in the English poem by a slow, reflective intonation typical of modern British poetry.In free translations, when there is initially no installation to convey the original text in any way at all, the discrepancy between national concept spheres manifests itself most clearly. In the English text, the theme of the Motherland, which has not received such distribution in British poetry as in Russian, is replaced by the theme of creativity / poet and poetry.The concept "Motherland", and the concepts of "England" and "Home" more characteristic of the English mentality, is coming to the forefront. "Dal" with its vastness is replaced by "distance" with its "measurement", which more corresponds to the empirical consciousness of the British, who are in actual accuracy and certainty. Consciously and consistently removed in translation is a lyricallytense, agitated intonation of a color poem created by playing assonances and alliteration, paronymic attraction, as well as punctuation marks. The poem 


\begin{tabular}{|c|c|c|c|c|c|c|}
\hline \multirow{4}{*}{ Impact Factor: } & ISRA (India) & $=3.117$ & SIS (USA) & $=0.912$ & ICV (Poland) & $=6.630$ \\
\hline & ISI (Dubai, UAI & $=0.829$ & РИНЦ (Russia & $=0.156$ & PIF (India) & $=1.940$ \\
\hline & GIF (Australia) & $=0.564$ & ESJI (KZ) & $=8.716$ & IBI (India) & $=4.260$ \\
\hline & JIF & $=1.500$ & SJIF (Morocco & $=5.667$ & OAJI (USA) & $=0.350$ \\
\hline
\end{tabular}

Shepkott has a more loose structure and, as is common in modern English poetry, does not rhyme.

\section{References:}

1. Poetry Review. Autumn 1993, vol.83, \#

2. Block A.A. Notebooks. 1901-1920. M., 1965C. Rice, GI Vermeer "Translation Studies - New Orientation", 1986

3. Osipova N. O. The creative work of M.I. Tsvetaeva in the context of the Silver Age cultural mythology. Kirov. 2000

4. Palievsky P.V. Russian classics. M., 1987

5. Tsvetkova, MV The Problem of National Identity, as a Translation Problem, Nizhny Novgorod, 2001

6. Tsvetkova M.V. The concept of ENGLISHNESS: main constants. / / The problem of national identity in the culture and education of Russia and the West. Voronezh. 2000.

7. Chelyshev E. P. Comprehension of the Russian national genius, M., 2002

8. Mirzakholov Kh. T. AKTUAL"NYE PROBLEMY INNOVATSIONNOGO
SODERZhANIYa KAChESTVA VYSShEGO OBRAZOVANIYa //Teoriya i praktika sovremennoy nauki. - 2017. - №. 4. - S. 622625.

9. Farkhodzhonova N. F. PROBLEMY PRIMENENIYa INNOVATSIONNYKh TEKhNOLOGIY V OBRAZOVATEL"NOM PROTsESSE NA MEZhDUNARODNOM UROVNE //Innovatsionnye tendentsii, sotsial'no-ekonomicheskie i pravovye problemy vzaimodeystviya v mezhdunarodnom prostranstve. - 2016. - S. 58-61.

10. Karimbaeva S. I. i dr. Urbanizatsiya-faktor obshchestvennogo razvitiya //Vysshaya shkola. - 2016. - №. 8. - S. 76-77.

11. Muxiddinova $X$. G. THE ROLE OF INFORMATION IN THE DEVELOPMENT OF THE SOCIETY //Ekonomikaisotsium. 2018. - №. 9. - S. 45-47. 